\title{
PREREQUISITES FOR CREATION MINING AND CHEMICAL ENTERPRISE
}

\section{Pavlo Saik ${ }^{1}$ \\ Vasyl Lozynskyi ${ }^{2}$}

DOI: https://doi.org/10.30525/978-9934-588-84-6-20

Progressive forms of mining enterprises organization provide for the transformation of traditional approaches to planning and technical re-equipment of production processes. The development of scientific and technological progress in the coal industry involves a change in priorities in the assessment of alternative options for updating production processes. Instead of traditional quantitative parameters, priority is given to qualitative factors of non-traditional production. They ensure maximum efficiency in the use of coal deposits, taking into account the relationship of resource and environmental components of mining processes [1, p. 223; 2, p. 130].

It is clear that mining companies can no longer focus on the further development of traditional mining technologies. This situation encourages a fundamentally new approach to the development of deposits based on underground gasification technologies [3, p. 14; 4, p. 329]. With the introduction of this technology, the format of the enterprise changes from mining and mining and chemical. The main structural unit of which is the power complex. The formation of energy-chemical complexes takes place in the industrial areas of the mine, so an additional source of energy is the generation of thermal energy.

Components which should be involved in the process of coal gasification within its occurrence are as follows: changes in technological parameters of underground gasifiers [5, p. 70, 72], mining and technical [6, p. 488] and mining and geological situations [7, p. 99] in gasification area. In this case, wastes should not be considered as a pollutant, but as a secondary resource for utilization in the technological process. For example, during underground coal gasification, the greenhouse gas emissions from a gas turbine can be directed to an underground gas generator to produce combustible gas - carbon monoxide by the reaction $\mathrm{CO}_{2}+\mathrm{C}=2 \mathrm{CO}$.

${ }^{1}$ Dnipro University of Technology, Ukraine

2 Dnipro University of Technology, Ukraine 
Borehole underground coal gasification technology (BUCG) allows the use of the following combinations of mining and chemical production: BUCG-production of power and synthesis gas; BUCG-gas and steam turbines for the production of electricity and heat; BUCG-production of biogas for further mixing with BUCG gas and increase the consumer properties of coal gas; BUCG-chemical complex for the production of motor fuels, methanol, ammonia and other chemical products; BUCGutilization complex for the transformation of low-potential thermal energy of exhaust gases.

Power gas providing the generation of electricity, technical gas and condensate for the production of chemical raw material (Figure 1) as well as the heat of gasification products and rocks enclosing the gasifier are basic products of BUCG station. The formed energy and chemical complex gives the most expedient possibility for the complete use of thermal energy.

The efficiency of a gasification process was evaluated by studying material and heat indices of the process. To do that, the authors of the paper used the software product «MTB-SPGU» which has been approbated industrially in terms of a gas generator (Barbara mine, Poland) [8, p. 1].

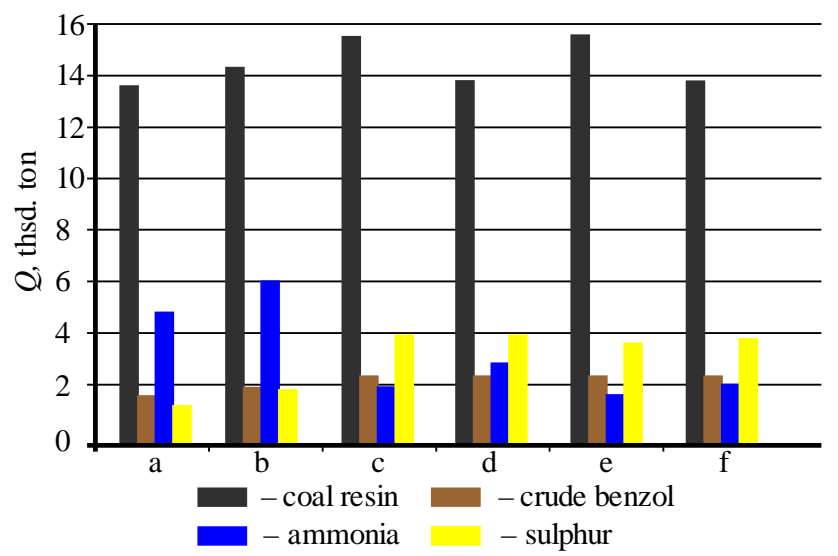

Figure 1. Output of chemical products in terms of gasification of gas coal seam (Lviv-Volyn coal basin, Lviv region, Ukaine): a - air forced draft;

$\mathrm{b}$ - water and vapour forced draft; $\mathrm{c}$ - oxygenic $\left(\mathrm{O}_{2}=65 \%\right)$;

$\mathrm{d}$ - vapour and oxygenic; $\mathrm{e}$ - carbon and oxygenic $\left(\mathrm{O}_{2}+\mathrm{CO}_{2}\right)$;

$\mathrm{f}$ - vapour, carbon and oxygenic; $\left(\mathrm{H}_{2} \mathrm{O}\right.$ (vapour) $+\mathrm{O}_{2}+\mathrm{CO}_{2}$ 
Gasification of coal formations should involve information concerning thickness of solid fuel seams. In compliance with the proper criteria taking into consideration the current state of engineering science, in terms of enclosing roof and floor undermining and overmining, such solid fuel seams are suitable for UCG [9, p. 101].

Generator gas flows through gas-outlet well to the surface is a vapourgas mixture of solid fuel gasification products; when the mixture cools down, liquid phase (condensate) and gaseous phase are formed. While cooling down, the condensate is divided into resin water solution of various chemical compounds and resin. UCG gas contains $0.3-0.7 \mathrm{~g} / \mathrm{m}^{3}$ of coal dust and rock dust, chimney soot and other inclusions.

Temperature of residual UCG gases heat is rather high $\left(300-600{ }^{\circ} \mathrm{C}\right)$. Taking into consideration features of the UCG method, authors of the paper have designed a heat utilizer providing the possibility to use power by generator gas in the process of underground gasifier operation. To compare with standard heat utilizers it is far more advantageous both in terms of its design and economic expediency.

Taking into consideration current tendencies of cogeneration technologies development, free-piston units (FPUs), accumulators of heat energy, gas-vapour turbine, and combined system of power resources generation using unified energy carrier - artificial gas generated on the basis of borehole underground coal gasification.

Cogeneration, combined technology of energy generation is applied both in the process of solid fuel seams gasification and after the process termination using the heat accumulated within the rock strata enclosing the gasifier. Payback period of such a cogeneration plant on the basis of gasturbine engines taking into account the prices for electricity is 1.4-2.5 years.

Generator gas is used to generate electricity and thermal energy in a group of vapour gas turbines, FPUs. In this context, combustion products from turbines and units are supplied to a waste-heat boiler to generate vapour applied to generate heat or electricity. Residual heat of outcoming gases from the waste-heat boiler is reused within two thermal accumulators: autonomous peak circuit to generate electricity and within underground accumulator to utilize heat for heat-supplying needs. Vapour generators mounted in the wells of underground gasifier utilize the heat of generator gases, and vapour being formed in the generator is supplied for vapour-water electricity generation and partially for underground accumulator. Accumulators collect, store, and generate thermal energy. The system of thermal energy accumulation makes it possible for combined electric power station to operate 3-5 hours in a peak mode. 
Use of heat as an intermediate energy carrier of heat-intensive liquid (technical oil, brine solution, glycol etc.) in the process of accumulation makes it possible to improve the efficiency of cogeneration station by $60 \%$ in terms of peak mode. Implementation of such principle of energy cogeneration in terms of BUCG provides fuel saving up to $35 \%$, and the process efficiency is $44-52 \%$.

This work was supported by the Ministry of Education and Science of Ukraine, grant No. 0119U000248.

\section{References:}

1. Saik, P., Petlevanyi, M., Lozynskyi, V., Sai, K., \& Merzlikin, A. (2018). Innovative approach to the integrated use of energy resources of underground coal gasification. Solid State Phenomena, (277), 221-231. doi: https://doi.org/10.4028/ www.scientific.net/SSP.277.221

2. Piwniak, G. G., Bondarenko, V. I., Salli, V. I., Pavlenko, I. I., \& Dychkovskiy, R. O. (2007). Limits to economic viability of extraction of thin coal seams in Ukraine. Technical, Technological and Economic Aspects of Thin-Seams Coal Mining, 129-132. doi: https://doi.org/10.1201/noe0415436700.ch16

3. Pivnyak, G., Dychkovskyi, R., Bobyliov, O., Cabana, E. C., \& Smoliński, A. (2018). Mathematical and Geomechanical Model in Physical and Chemical Processes of Underground Coal Gasification. Solid State Phenomena, (277), 1-16. doi: https://doi.org/10.4028/www.scientific.net/ssp.277.1

4. Rosen, M. A., Reddy, B. V., \& Self, S. J. (2018). Underground coal gasification (UCG) modeling and analysis. Underground Coal Gasification and Combustion, 329-362. doi: https://doi.org/10.1016/b978-0-08-100313-8.00011-6

5. Falshtynskyi, V., Saik, P., Lozynskyi, V., Dychkovskyi, R., \& Petlovanyi, M. (2018). Innovative aspects of underground coal gasification technology in mine conditions. Mining of Mineral Deposits, 12(2), 68-75. doi: https://doi.org/10.15407/ mining12.02.068

6. Xin, L., Wang, Z., Wang, G., Nie, W., Zhou, G., Cheng, W., \& Xie, J. (2017). Technological aspects for underground coal gasification in steeply inclined thin coal seams at Zhongliangshan coal mine in China. Fuel, 191, 486-494. doi: https://doi.org/10.1016/j.fuel.2016.11.102

7. Sadovenko, I., Inkin, O., \& Zagrytsenko, A. (2016). Theoretical and geotechnological fundamentals for the development of natural and man-made resources of coal deposits. Mining of Mineral Deposits, 10(4), 1-10. doi: https://doi.org//10.15407/mining10.04.001

8. Saik, P., Dychkovskyi, R., Lozynskyi, V., Falshtynskyi, V., Cabana, E., \& Hrytsenko, L. (2020). Studying the features of the implementation of underground coal gasification technology in terms of Lvivvuhillia SE. E3S Web of Conferences, (168), 00036. doi: https://doi.org/10.1051/e3sconf/202016800036

9. Pei, P., Nasah, J., Solc, J., Korom, S.F., Laudal, D., \& Barse, K. (2016). Investigation of the feasibility of underground coal gasification in North Dakota, United States. Energy Conversion and Management, 95-103. doi: https://doi.org/ 10.1016/j.enconman.2016.01.053 